\title{
NEUROPROTECTION OF ABELMOSCHUS ESCULENTUS L. AGAINST DIABETIC NEUROPATHY
}

\section{LEE WEI YANG ${ }^{1}$, SANTOSH FATTEPUR ${ }^{1}$, KIRAN CHANABASAPPA NILUGAL ${ }^{*}{ }^{*}$, FADLI ASMANI $^{2}$, EDDY YUSUF ${ }^{2}$, MOHD NIZAM ABDUL GHANI ${ }^{2}$, IBRAHIM ABDULLAH ${ }^{2}$}

${ }^{1}$ Departement of Pharmacology, School of Pharmacy, Management and Science University, Shah Alam Selangor, Malaysia. ${ }^{2}$ Department of Clinical pharmacy, School of Pharmacy, Management and Science University Shah Alam, Selangor, Malaysia. Email: kirannilugal@gmail.com

Received: 07 November 2017, Revised and Accepted: 20 April 2018

ABSTRACT

Objective: The present study was designed to determine the neuroprotective effect of Abelmoschus esculentus L. on alloxan-induced diabetic neuropathy in rats.

Methods: Diabetes was induced in rats with a single intraperitoneal injection of alloxan monohydrate (130 mg/kg b.w). The ethanol extract of A. esculentus L. at a dose of 100 and $200 \mathrm{mg} / \mathrm{kg}$ of body weight was administered at single dose per day to alloxan-induced diabetic rats for 21 days. The fasting blood glucose was screened in the intermittent on day 0 , day 14 , and day 21 . Behavioral tests such as thermal hyperalgesia test and rotarod performance test were performed to assess the thermal sensitivity and muscle grip strength. At the end of the study period, experimental animals were sacrificed and sciatic nerve tissues were obtained for histopathological investigation.

Results: Animals treated with A. esculentus L. extarct at a dose of $200 \mathrm{mg} / \mathrm{kg}$ of body weight significantly reduced (p<0.05) in hyperglycemia and thermal hyperalgesia and significantly increased $(\mathrm{p}<0.05)$ in rotarod performance. The sciatic nerve fiber of diabetic rats receiving $200 \mathrm{mg} / \mathrm{kg}$ of body weight of $A$. esculentus L. extract also shows no swelling of nerve fibers, and lesser demyelination was observed.

Conclusion: These findings demonstrate that A. esculentus L. exhibits significant antidiabetic and neuroprotective effect against alloxan-induced diabetic neuropathy in rats.

Keywords: Abelmoschus esculentus L, Neuroprotective, Antidiabetic, Histopathological investigation.

(C) 2018 The Authors. Published by Innovare Academic Sciences Pvt Ltd. This is an open access article under the CC BY license (http://creativecommons. org/licenses/by/4. 0/) DOI: http://dx.doi.org/10.22159/ajpcr.2018.v11s3.30023

\section{INTRODUCTION}

Diabetes mellitus is a condition where body either does not produce enough insulin or response to insulin. According to the International Diabetes Foundation, in 2014, there were 3.3 million cases of diabetes in Malaysia. The prevalence of diabetes in adults between 20 and 79 years was $16.61 \%$ in 2015 . The cost per person with diabetes was 565.35 USD [1].

Diabetes mellitus is best known as a multifactorial metabolic disorder characterized by chronic hyperglycemia with abnormal carbohydrate, protein, and fat metabolism due to deficiency of insulin or failure of body response to insulin or both [2]. Long-term exposure of organ to hyperglycemia could lead to chronic complication such as microvascular and macrovascular complications. Examples of microvascular diseases of diabetes are diabetic retinopathy, diabetic neuropathy, and diabetic nephropathy while macrovascular disease is atherosclerosis. In short term, acute complications cause clinical manifestation such as polydipsia, polyuria, glycosuria, and polyphagia [3].

Diabetic neuropathy is defined as the presence of signs and symptoms of nerve fiber dysfunction in people with chronic hyperglycemia [4]. Approximately $50 \%$ of patients with long-standing type 1 and type 2 diabetes mellitus have developed diabetic neuropathy. In fact, diabetic neuropathy is likely to affect 23 million of 472 million patients with diabetes by 2030 [5]. It may be classified as polyneuropathy, mononeuropathy, and autonomic neuropathy. The risk factors are long duration hyperglycemia, poor control of glucose in blood, smoking, heavy alcohol intake, hypertension, and elevated triglycerides [6].

The diabetic neuropathy is due to the background of hyperglycemia, so investigation on the pathophysiology of diabetic neuropathy is mainly concerned [7]. The pathogenesis of diabetic neuropathy is not fully understood, but a number of theories can be described [8]. One of the important factors associated with diabetes mellitus is oxidative stress [7]. The oxidative stress is due to free radical production responded from activation of polyol pathway, advanced glycation end products, hexosamine, and diacylglycerol/protein kinase $C[9,10]$.

The Abelmoschus esculentus L. aka Okra or lady's finger is a flowering plant in the mallow family [11]. Okra immature fruits can be taken as vegetables or can be used with soup, salads, fresh or dried, fried, or boiled [12]. Okra is a powerhouse of valuable nutrients. Approximate half of it is soluble fibers in the form of gums and pectins while the rest are insoluble fibers, proteins, carbohydrates, minerals, and vitamins. Okra is also best known as antioxidant vegetable and has very good benefit on cardiovascular disease, Type 2 diabetes mellitus, digestive disease, and some cancer [13]. The medicinal values of Okra were revealed and reported to have properties on reducing blood glucose, lowering blood lipid, and neuroprotection [14,15]. This research is undertaken to investigate in vivo antioxidant and antidiabetic activity of Okra as well as its neuroprotection effects in alloxan-induced diabetic rats.

\section{METHODS}

\section{Plant materials}

$7 \mathrm{~kg}$ of A. esculentus L. (Okra) was obtained from Pasar Besar Klang located in Klang which is in the state of Selangor, Malaysia. The plant material was identified by a resident botanist through comparison with specimen A. esculentus L. kept at the Forest Research Institute Malaysia.

\section{Experimental animals}

Male Sprague Dawley albino rats (150-200 g) were used to assess in this experiment. The animals were kept and maintained under 
standard laboratory conditions (temperature $\left[22^{\circ} \mathrm{C} \pm 2^{\circ} \mathrm{C}\right]$ and humidity $\left.\left[45^{\circ} \mathrm{C} \pm 5^{\circ} \mathrm{C}\right]\right)$ with $12: 12 \mathrm{~h}$ day:night cycle. The animals were fed with standard laboratory diet and allowed to drink water. Studies were carried out in accordance with the Institutional Ethical Guidelines for the care of laboratory animals of Management and Science University, Malaysia.

\section{Development of diabetes mellitus model in rats}

The rats are fasted overnight. Diabetes is induced by intraperitoneal (i.p.) injection of alloxan monohydrate at a dose of $150 \mathrm{mg} / \mathrm{kg}$ body weight in $0.1 \mathrm{M}$ cold citrate buffer ( $\mathrm{pH} 4.5$ ). To prevent alloxan-induced hypoglycemia, $10 \%$ dextrose solution is given to rats after $6 \mathrm{~h}$ of alloxan administration for next $24 \mathrm{~h}$. Induction of diabetes is verified after $72 \mathrm{~h}$ by measuring blood glucose levels with strips using glucometer, and the animals are allowed 14 days for the stabilization of blood glucose level. If the blood glucose in rats has higher than $250 \mathrm{mg} / \mathrm{L}$ after day 14 , animals are considered diabetic and used in experiment [16].

\section{Preparation of A. esculentus L. extract}

The A. esculentus L. is dried in the hot air oven at $60^{\circ} \mathrm{C}$. The dried okra is made into fine powders using a blender. The fine powders will be extracted in $95 \%$ ethanol solvent using Soxhlet extraction method. Sequential extractions are performed. The extract (AeL extract) is evaporated at $60^{\circ} \mathrm{C}$ in a rotary evaporator. The remaining extract is dried in room temperature for several days to ensure the removal of any residual solvent [17].

Treatment of AeL extract to Alloxan-induced diabetic rat (positive vs. negative control)

Animals are divided into five groups, and each group consisted of 6 rats. The grouping details are follows:

- Group I - Normal/control animals received $1 \%$ tween $80,3 \mathrm{ml} / \mathrm{kg}$ body weight per orally.

- Group II - Alloxan-induced diabetic rats received $1 \%$ tween 80 , $3 \mathrm{ml} / \mathrm{kg}$ body weight per orally.

- Group III - Alloxan-induced diabetic rats received glibenclamide $5 \mathrm{mg} / \mathrm{kg}$.

- Group V - Alloxan-induced diabetic rats received okra extract $100 \mathrm{mg} / \mathrm{kg}$ dissolved in 1\% Tween-80.

- Group VI - Alloxan-induced diabetic rats received okra extract $200 \mathrm{mg} / \mathrm{kg}$ dissolved in 1\% Tween-80.

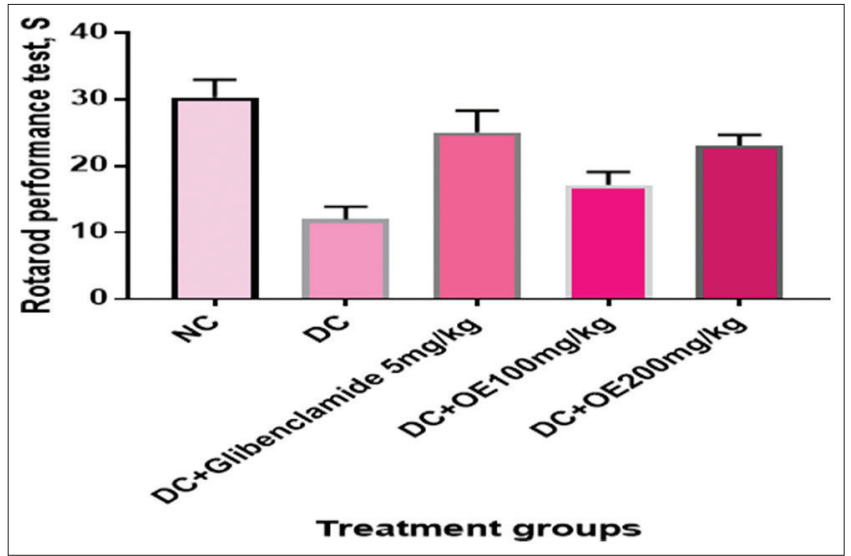

Graph 1: Histological and morphological study of sciatic nerve
Each group of rats is fed and observed for 30 days. After 30 days, the blood glucose level of each group of rats is determined with strips using glucometer and recorded [18].

\section{Behavioral investigation}

Thermal hyperalgesia test

Neuropathic pain is evaluated using Eddy's hot plate, which is an instrument designed by Eddy et al. to assess thermal sensitivity. The plate was preheated and each of the rats is put on the hot plate at fixed temperature of $55^{\circ} \mathrm{C}$, and the rat was placed on the hot plate and nociceptive threshold, with respect to licking of the hind paw or jumping, was recorded in seconds. The cutoff time of $20 \mathrm{~s}$ was maintained [19].

\section{Rotarod performance test}

Rotarod performance test is used to evaluate balance and sensory-motor coordination of the subjects. The speed is accelerated to $40 \mathrm{rpm} / \mathrm{min}$. The fallingtimeofeachratfromrotatingspindlewasrecordedduring 5 minperiod. Mean change in the locomotor activity was recorded for each group [20].

\section{Histological and morphological study of sciatic nerve}

The rat is anesthetized using ketamine, i.p. injection, $70 \mathrm{mg} / \mathrm{kg}$. According to Suri et al., 2002, and Martins et al., 2005, rat is placed in prone position and sciatic nerve is exposed at the dorsocaudal region. An incision is made strating $0.5 \mathrm{~cm}$ laterally from the animal's midline and extending laterally for $3 \mathrm{~cm}$ toward the tibiofemoral articulation. The femoral biceps and gluteus muscles are separated using blunt dissection to allow access to provide exposure of the sciatic nerve. Then, the nerve is fixed in situ for 20 min with $4 \%$ glutaraldehyde in $0.1 \mathrm{M}$ of phosphate-buffered saline at $\mathrm{pH} 7.4$. The sciatic nerve is cut from the sciatic notch to the knee level and immersed in $2.5 \%$ glutaraldehyde in $0.1 \mathrm{M}$ phosphate buffer solution at $\mathrm{pH} 7.4$ for overnight. Then, approximately $3 \mathrm{~mm}$ lengths of sciatic nerve are cut and post-fixed for $2 \mathrm{~h}$ in $1 \%$ buffered osmium tetroxide and dehydrated in graded concentrations of acetone and embedded in epoxy resin. A thin layer of transverse section of sciatic nerve is cut using blade and stained with $1 \%$ toluidine blue and observe under a light microscope. The morphological changes of sciatic nerve between normal control group, diabetes- induced, and treatment rats are observed.

\section{Statistical analysis}

Significance of differences between the mean values was determined by the analysis of variance (ANOVA), followed by Dunnett's test. SPSS 24, USA, was used for statistical analysis. Graphs were prepared using GraphPad Prism 7. Results were considered statistically significant when the $P<0.05$.

\section{RESULTS}

\section{Induction of diabetes}

Of total 45 rats that were induced, 10 of them dead due to severe high blood glucose and 5 of them were failed to become diabetes before the treatment was given.

Effects of okra extracts on blood glucose level in alloxan-induced diabetic rats

Thermal hyperalgesia test [Tables 1-3]

Table 1: Effect of daily oral administration of extracts on blood glucose level of alloxan-induced diabetic rats

\begin{tabular}{llc}
\hline Treatment groups & \multicolumn{2}{l}{ Fasting blood glucose (mmol/L) } \\
\cline { 2 - 3 } & Day 0 & Day 14 \\
\hline Normal control & $6.00 \pm 0.63$ & $5.92 \pm 0.41$ \\
Diabetic control & $14.07 \pm 1.89$ & $12.95 \pm 2.25$ \\
Diabetic control with glibenclamide $(5 \mathrm{mg} / \mathrm{kg})$ & $15.27 \pm 1.46$ & $10.81 \pm 0.88$ \\
Diabetic control with Okra extract $(100 \mathrm{mg} / \mathrm{kg})$ & $12.40 \pm 1.36$ & $11.23 \pm 1.22$ \\
Diabetic control with Okra extract $(200 \mathrm{mg} / \mathrm{kg})$ & $13.75 \pm 0.87$ & $10.75 \pm 1.58$ \\
\hline
\end{tabular}

Values are given as mean \pm S.E.M for 6 rats in each group $(\mathrm{n}=6) .{ }^{*} \mathrm{p}<0.05=$ glibenclamide and $200 \mathrm{mg} / \mathrm{kg}$ compared with diabetic control. S.E.M: Standard error of the mean 
Table 2: Effect of Abelmoschus esculentus L. extract on rats subjected to paw heat-hyperalgesia test

\begin{tabular}{ll}
\hline Treatment groups & $\begin{array}{l}\text { Reaction } \\
\text { time (s) }\end{array}$ \\
\cline { 2 - 2 } & $\begin{array}{l}\text { Day 21 (end of } \\
\text { treatment) }\end{array}$ \\
\hline Normal control & $14.09 \pm 1.18$ \\
Diabetic control & $8.29 \pm 0.83^{\mathrm{a}}$ \\
Diabetic control with glibenclamide $(5 \mathrm{mg} / \mathrm{kg})$ & $12.24 \pm 0.70^{*}$ \\
Diabetic control with okra extract $(100 \mathrm{mg} / \mathrm{kg})$ & $9.74 \pm 0.42$ \\
Diabetic control with okra extract $(200 \mathrm{mg} / \mathrm{kg})$ & $12.46 \pm 0.71^{*}$ \\
\hline
\end{tabular}

Values are given as mean \pm S.E.M for 6 rats in each group $(n=6) .{ }^{a} \mathrm{p}<0.05=$ diabetic control compared with normal control ${ }^{*} \mathrm{p}<0.05=$ glibenclamide and $\mathrm{OE}$

$100 \mathrm{mg} / \mathrm{kg}$ compared with diabetic control. S.E.M: Standard error of the mean

Table 3: Effect of Abelmoschus esculentus L. extract on rats subjected to motor coordination test

\begin{tabular}{ll}
\hline Treatment groups Day 21 (end of treatment) & $\begin{array}{l}\text { Reaction } \\
\text { time (s) }\end{array}$ \\
\cline { 2 - 2 } & \\
Normal control & $30.27 \pm 2.70$ \\
Diabetic control & $11.95 \pm 1.94^{a}$ \\
Diabetic control with glibenclamide $(5 \mathrm{mg} / \mathrm{kg})$ & $25.05 \pm 3.24^{*}$ \\
Diabetic control with okra extract $(100 \mathrm{mg} / \mathrm{kg})$ & $17.15 \pm 1.95$ \\
Diabetic control with okra extract $(200 \mathrm{mg} / \mathrm{kg})$ & $23.08 \pm 1.58^{*}$ \\
\hline
\end{tabular}

Values are given as mean \pm S.E.M for 6 rats in each group $(n=6)$. ${ }^{\mathrm{a}} \mathrm{p}<0.05=$ diabetic control compared with normal control, whereas *p $<0.05=$ glibenclamide and $\mathrm{OE}$ $100 \mathrm{mg} / \mathrm{kg}$ compared with diabetic control. S.E.M: Standard error of the mean

\section{Rotarod performance test}

Fig. 3a shows the normal control group of sciatic nerve. Fig. 3b shows sciatic nerve fiber of diabetic control group. There is obvious edema around the epineurium and leakage and infiltration of neutrophils around blood vessels, and swelling of nerve fibers (red arrow) was observed. Fig. 3c shows the sciatic nerve fiber of diabetic rats receiving glibenclamide $(5 \mathrm{mg} / \mathrm{kg})$. There are no obvious edema and infiltration of neutrophils into the nerve fiber bundle peaks, and no fiber swelling and demyelination were observed. Fig. $3 \mathrm{~d}$ shows sciatic nerve fiber of diabetic rats receiving okra extract $(100 \mathrm{mg} / \mathrm{kg}$ ). Swelling of nerve fibers (red arrow) was observed, and partial demyelination was seen. Fig. 3e shows sciatic nerve fiber of diabetic rats receiving okra extract $(200 \mathrm{mg} / \mathrm{kg})$. No swelling of nerve fibers and lesser demyelination were observed.

\section{DISCUSSION}

In this study, A. esculentus L. extract was given as neuroprotection of sciatic nerve in alloxan-induced diabetic rats. Alloxan gain popularity to induce type-1 diabetes in rodents which resembles to human insulin dependent diabetes mellitus. Alloxan has its property of diabetogenicity by reacting with two-SH groups in the sugar binding site of glucokinase, resulting in the formation of the disulfide bond and inactivation of the enzyme. Glucokinase inhibition reduces glucose oxidation and ATP generation that further suppresses glucose-induced insulin secretion. In addition, alloxan also inhibits the biosynthesis of insulin through the same mechanism [21].

At day 0, a marked rise in fasting blood glucose level was observed in alloxan-treated groups as compared to normal group. At day 14 , there are no significant differences between the treatment groups (glibenclamide $5 \mathrm{mg} / \mathrm{kg}$ and okra extract $100 \mathrm{mg} / \mathrm{kg}$ and $200 \mathrm{mg} / \mathrm{kg}$ ) compared to diabetic control, whereas, at day 21 , treatment with glibenclamide and okra extract $200 \mathrm{mg} / \mathrm{kg}$ caused significant reduction $(\mathrm{p}<0.05)$ in the levels of fasting blood glucose compared with diabetic control. 32.6\% reduction in fasting blood glucose from day 0 to day (Fig. 1). Thus, okra extract at dose of $200 \mathrm{mg} / \mathrm{kg}$ had demonstrated antiglycemic activity in alloxan-induced diabetic rats. The antiglycemic effect of $A$. esculentus $\mathrm{L}$.

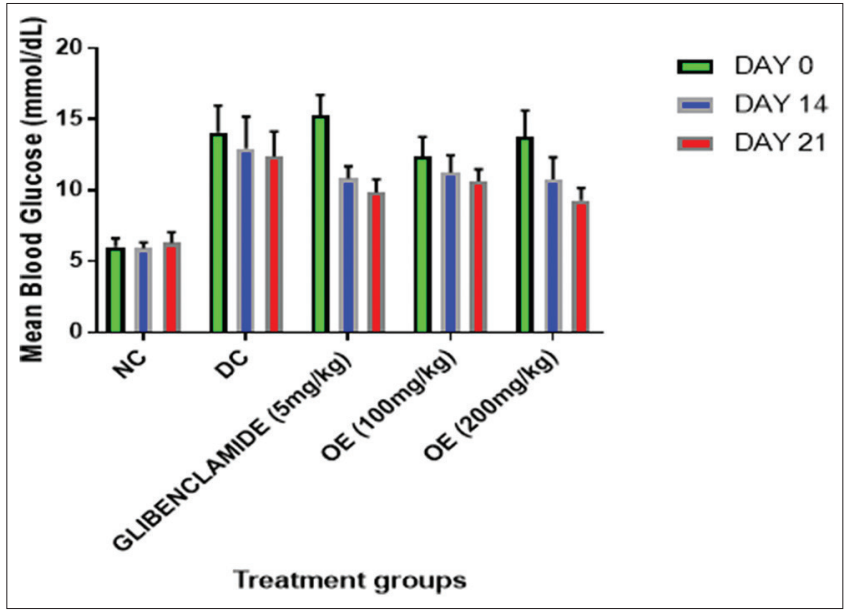

Fig. 1: Effect of Abelmoschus esculentus L. extracts on fasting blood glucose concentration of alloxan-induced diabetic rats

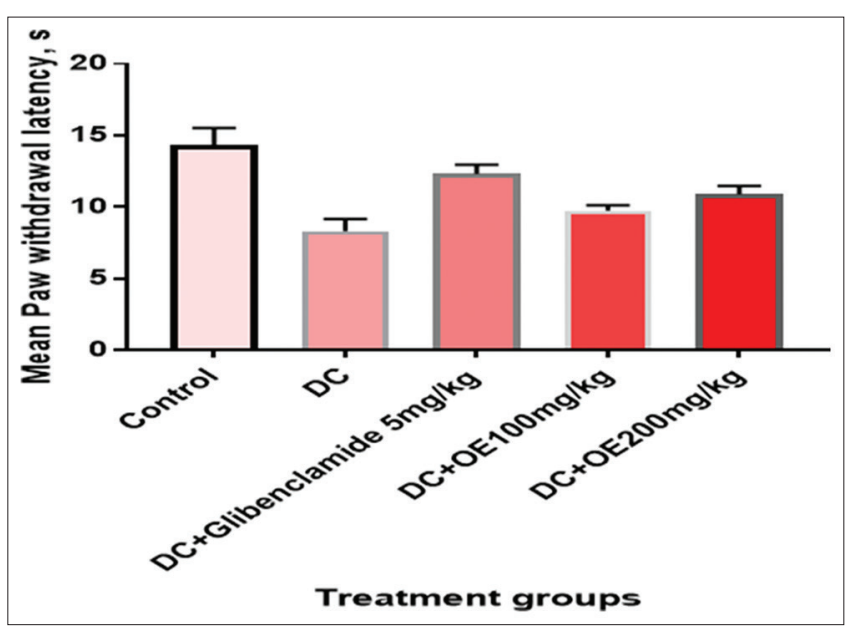

Fig. 2: Effect of Abelmoschus esculentus L. extracts on rats subjected to paw heat-hyperalgesia test

may due to isoquercetin and quercetin-3-0-beta-glucopyranosyl-(1"'--> 6 ")-glucoside isolated from the okra seed extract and was selectivity inhibited rat intestinal maltase and sucrose.

In first behavioral examination, diabetic rats were shown significant reduction in paw withdrawal latency compared with normal control rats, shown in Fig. 2, indicating that the diabetic rats decreased in nociceptive threshold to heat, resulting hyperalgesia. Other than that diabetic rats treated with $A$. esculentus L. extract in $200 \mathrm{mg} / \mathrm{kg}$ were shown significant reduction $(\mathrm{p}<0.05)$ in paw withdrawal latency compared with diabetic control rats. Thus, $200 \mathrm{mg} / \mathrm{kg}$ A. esculentus $\mathrm{L}$. extract shows neuroprotection effect on alloxan-induced diabetic rats.

In second behavioral examination, diabetic rats were shown significant reduction in Rotarod performance compared with normal control rats (Graph 1), indicating a decrease in muscle grip strength of legs due to impairment of sciatic nerve. Other than that, diabetic rats treated with A. esculentus L. extract in $200 \mathrm{mg} / \mathrm{kg}$ were shown significant reduction $(\mathrm{p}<0.05)$ in Rotarod performance compared with diabetic control rats. Thus, $200 \mathrm{mg} / \mathrm{kg}$ A. esculentus L. extract shows neuroprotection effect on alloxan-induced diabetic rats.

As the most common complications of diabetes, diabetic neuropathy is characterized by the signs and symptoms of nerve fiber dysfunction in people with chronic hyperglycemia [4]. In this study, we further evaluated the role of $A$. esculentus L. extraction diabetic neuropathy 


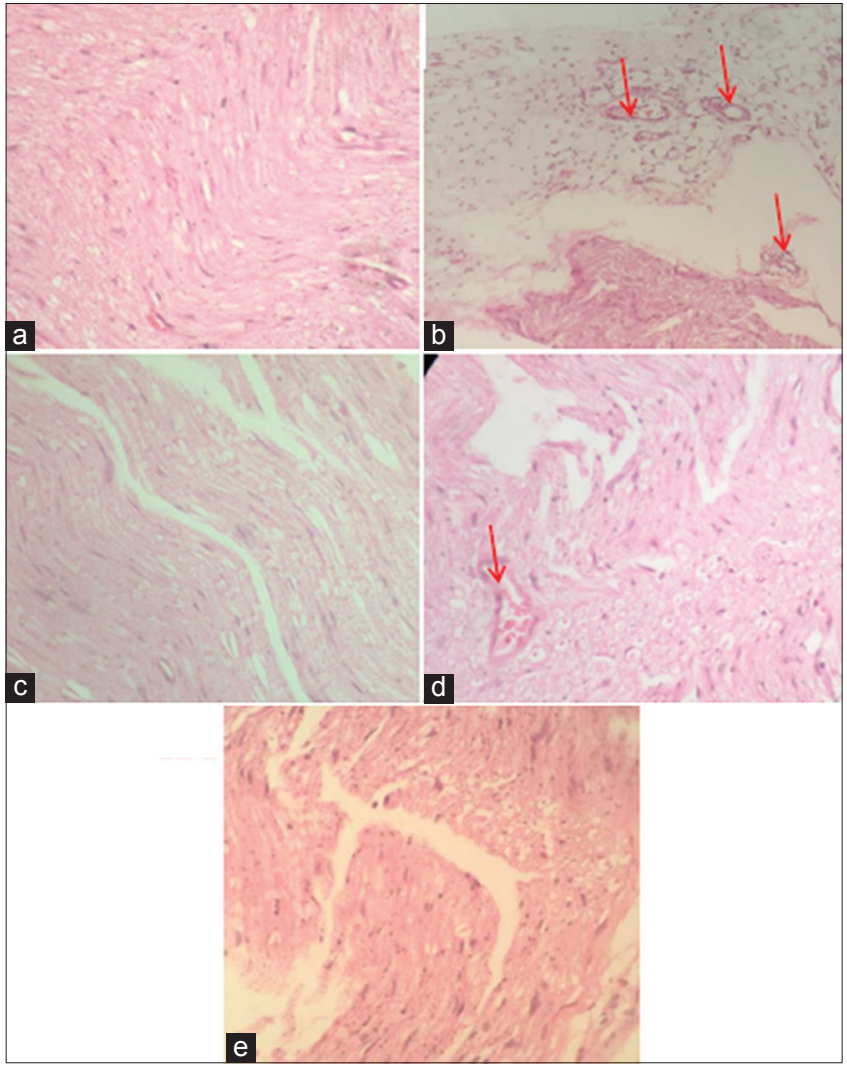

Fig. 3: Effect of Abelmoschus esculentus L. extracts on rats subjected Rotarod performance test

in rat, and our morphological study of sciatic nerve revealed that administration of $A$. esculentus $\mathrm{L}$. extract, especially at dose of $200 \mathrm{mg} / \mathrm{kg}$, shows no swelling in nerve fibers and lesser extent of demyelination to close to the control group.

Therefore, dose dependence of $200 \mathrm{mg} / \mathrm{kg}$ body weight of A. esculentus L. extract was proposed its antidiabetic and neuroprotective effect whereby it exerts a substantial protective effect against alloxan-induced diabetic neuropathy in sciatic nerve of rats.

\section{CONCLUSION}

The present study has shown that dose dependence of $200 \mathrm{mg} / \mathrm{kg}$ of the extract of $A$. esculentus L. has attenuated the alloxan-induced diabetic neuropathy in rats, whereas $100 \mathrm{mg} / \mathrm{kg}$ did not. These effects may be indirectly attributed to its potential anti-hyperglycemia properties. Which is causing a total $32.6 \%$ reduction in fasting blood glucose. These findings provide a therapeutic potential for future treatment of diabetic neuropathy. However, further studies are required to elucidate the mechanism of neuroprotection of $A$. esculentus $\mathrm{L}$. on sciatic nerve.
Besides, the treatment group of neuroprotective agent such as Vitamin B complex can be included as the standard treatment.

\section{REFERENCES}

1. International Diabetes Federation. Diabetes in Malaysia-2014; 2014. Available from: https://www.idf.org/sites/default/files/Atlasposter-2014_EN.pdf. [Last accessed on 2014 Jun].

2. The Expert Committee on the Diagnosis and Classification of Diabetes Mellitus. report of the expert committee on the diagnosis and classification of diabetes mellitus. Diabetes Care 2003;36 Suppl 2:1183-97.

3. Forbes JM, Cooper ME. Mechanisms of diabetic complications. Physiol Rev 2011;93:137-88.

4. Boulton AJ, Malik RA. Diabetic neuropathy. Med Clin North Am 1998;82:909-29.

5. Tesfaye S, Selvarajah D. Advances in the epidemiology, pathogenesis and management of diabetic peripheral neuropathy. Diabetes Metab Res Rev 2012;1:8-14.

6. Kasper D, Fauci A, Hauser S, Longo D, Jameson J, Loscalzo J. Harrison's Principles of Internal Medicine. $19^{\text {th }}$ ed. New York: McGrawHill, Medical Pub. Division; 2015.

7. Negi G, Kumar A, Joshi RP, Ruby PK, Sharma SS. Oxidative stress and diabetic neuropathy: Current status of antioxidants. Inst Integrat Omics Appl Biotechnol 2011;2:71-8.

8. Pourmand R. Diabetic neuropathy. Neurol Clin 1997;3:569-76.

9. Edwards JL, Vincent AM, Cheng HT, Feldman EL. Diabetic neuropathy: Mechanisms to managemen. Pharmacol Ther 2008;120:1-34.

10. Yagihashi S, Mizukami H, Sugimoto K. "Mechanism of diabetic neuropathy: Where are we now and where to go? J Diabetes Invest 2011;2:18-32.

11. Chopra RN, Nayar SL, Chopra IC. Glossary of Indian medicinal Plants. New Delhi: Council of Industrial and Scientific Research; 1956. p. 1-133.

12. Ndunguru J, Rajabu AC. Effect of okra mosaic virus disease on the above-ground morphological yield components of okra in Tanzania. Sci Horticul 2004;99:225-35.

13. Gemede HF, Ratta N, Haki GD, Woldegiorgis AZ, Beyene F. Nutritional quality and health benefits of okra (Abelmoschus esculentus): A review. Food Sci Q Manage 2015. DOI: 10.4172/2157-7110.1000458.

14. Subrahmanyam GV, Sushma M, Alekya A, Neeraja CH, Harsha HS, Ravindra J. Antidiabetic activity of Abelmoschus esculentus fruit extract. Int J Res Pharm Chem 2011;1:17-20.

15. Ngoc TH, Ngo QN, Van AT, Phung NV. Hypolipidemic effect of extracts from Abelmoschus esculentus L. (Malvaceae) on tyloxapolinduced hyperlipidemia in mice. Warasan Phesatchasat 2008;35:42-6.

16. Sabitha V, Ramachandran S, Naveen KR, Panneerselvam K. Investigation of in vivo antioxidant property of Abelmoschus esculentus (L). Oench. fruit seed and peel powders in streptozotocin-induced diabetic rats. J Ayurveda Integr Med 2012;3:188-93.

17. Pendre NK, Nema PK, Sharma HP, Rathore SS, Kushwah SS. Effect of drying temperature and slice size on quality of dried okra (Abelmoschus esculentus (L.) Moench). J Food Sci Technol 2012;49:378-81.

18. Raju S, Hemamalini K. In vivo animal model for screening of antidiabetic activity. Asian J Pharm Clin Res 2012;5:118-24.

19. Austin PJ, Wu A, Moalem-Taylor G. Chronic constriction of the sciatic nerve and pain hypersensitivity testing in rats. J Vis Exp 2012;61:3393.

20. Deacon RM. Measuring motor coordination in mice. J Vis Exp 2013;75:2609.

21. Rohilla A, Ali S. Alloxan induced diabetes: Mechanisms and effects. Int J Res Pharm Biomed Sci 2012;3:819-23. 